\title{
Effect of a Disability-Awareness Program about Hearing Loss on Awareness of Regular Students' Hearing Loss and Inclusive Education with Hearing-Impaired Students
}

\author{
Chan Mi Kim¹, Jae Hee Lee ${ }^{1,2}$ \\ 'Department of Audiology and Speech-Language Pathology, Hallym University of Graduate Studies, Seoul, Korea \\ ${ }^{2}$ HUGS Center for Hearing and Speech Research, Seoul, Korea \\ 청각장애이해 프로그램이 일반학생의 청각장애 및 청각장애학생과의 \\ 통합교육에 대한 인식에 미치는 효과 \\ 김 찬 미 ${ }^{1} \cdot$ 이 재 희 ${ }^{1,2}$ \\ 한림국제대학원대학교 청각언어치료학과 ${ }^{1}$, 한림청각언어연구소 ${ }^{2}$
}

\begin{abstract}
Purpose: Regular students' lack of knowledge about hearing and hearing loss can adversely impact their attitudes toward hearing loss, hearing care, and inclusion of students with hearing impairment. The purpose of this study was to investigate the effectiveness of a disability-awareness program about hearing loss on regular students' awareness of hearing loss and inclusive education with hearingimpaired students. Methods: In total, data of 142 middle school and high school students were used for analysis. A 90-minute disabilityawareness program about hearing loss was implemented one time. The program included both understanding-based and activity-based educations. For the understanding-based education, information about the normal hearing mechanism, the causes and risks of hearing loss, and the prevention of hearing loss were given. Also, some famous deaf people who overcame their hearing loss were introduced, and group discussion and presentation were conducted. For the activity-based education, the activities of simulated listening with hearing loss and of wearing hearing aids were given. Results: The regular students' awareness of hearing loss and hearing cares significantly improved after participating in one-time educational session, regardless of the grade. After participating in the program, the regular students reported more positive attitudes toward inclusive education with hearing-impaired students and agreed that the regular students would promote the communication and listening skills of hearing-impaired students. Among various activities, the activities of group discussion and presentation were the most favored. Conclusion: A disability-awareness program about hearing loss enhanced the awareness of the middle school and high school students regarding the risks and prevention of hearing loss, the importance of hearing health and care. The disability-awareness program also appeared to be positive on the regular students' accepting attitudes toward inclusive education with hearing-impaired students. It indicates a need for more systematic and structured disability-awareness programs on hearing loss and hearing care in the future.
\end{abstract}

Key Words: Disability-awareness program, Hearing loss, Hearing care, Inclusive education.

Received: March 24, 2019 / Revised: April 6, 2019 / Accepted: April 6, 2019

Correspondence: Jae Hee Lee, Department of Audiology and Speech-Language Pathology, Hallym University of Graduate Studies, 427 Yeoksam-ro, Gangnam-gu, Seoul 06197, Korea

Tel: +82-2-2051-4952 / Fax: +82-2-3451-6618 / E-mail: leejaehee@hallym.ac.kr

\section{INTRODUCTION}

우리나라는 1994년에 특수교육진흥법 제62조 6항을 개정한
이후 2007년, 2008년에 "장애인 등에 관한 특수교육법”, “장애 인차별금지 및 권리 규제 등에 관한 법률", “장애인복지법”, “장 애인 고용촉진 및 직업재활법” 등과 같은 장애인 관련 법률을

(c) This is an Open Access article distributed under the terms of the Creative Commons Attribution Non-Commercial License (https://creativecommons.org/licenses/ by-nc/4.0) which permits unrestricted non-commercial use, distribution, and reproduction in any medium, provided the original work is properly cited. 
제정 및 개정하였다. 이와 같은 법 개정을 통해 통합교육을 지향 하는 법적 기반을 마련한 이후 특수교육 대상자의 일반학교 배 치 수는 해마다 증가하였다. 그러나 통합교육의 성공을 위해서 는 일반학생과 장애학생을 물리적으로 한 공간에 통합시키는 것만으로 충분하지 않다(Cole \& Chan, 1990; Peterson, 1982). 통합교육을 실행하는 과정은 매우 복잡하며, 학생 요인, 또래(일 반학생) 요인, 교사와 교수적 요인, 행정적 요인, 부모 및 지역사 회의 태도 등의 여러 요인들이 통합교육의 성공 여부에 영향을 준다(Kang \& Choi, 2011; Won \& Um, 2007).

통합교육이란 교육 환경의 제한을 최소화하여 일반학생과 동등한 기회를 제공하여 사회적 통합, 즉 더불어 살아가는 공 동체를 제공하고자 하는 것이다. 더불어 살아가며 바람직한 상 호작용을 하기 위해서는 서로의 다름을 인정하고 존중하는 과 정이 필요한데 이를 위해서는 장애인에 대한 인식을 긍정적으 로 변화시켜줄 장애이해교육이 필수적이다. $\mathrm{Seo}(2017)$ 는 단순 한 자료 배부를 통한 기존의 교육방법보다는 다양한 자료를 활 용하는 이해중심 교육, 구조화된 체험 혹은 접촉을 중시하는 활동중심 교육이 장애수용 태도나 인식 개선에 보다 유리하다 고 하였다. 이해중심 교육에는 장애에 대한 정보 제공, 장애인 의 삶을 다룬 영화 혹은 책, 장애를 극복한 사람 소개, 장애 이 해에 관한 집단 토론 등이 포함된다. 활동중심 교육에서는 모 의 장애체험 등의 직간접적 경험을 제공하여 장애학생에 대한 수용 태도를 향상시키는 데 목적을 둔다.

다양한 선행연구에서 유아 및 초등학생들을 대상으로 장애이 해 교육활동을 시행하여 긍정적인 효과를 보고하였으며(Kim, 2007; Kwak et al., 1996) 특히 나이가 어릴수록 청각장애뿐 아 니라 지체부자유, 학습장애, 지적 장애 등에 대한 인식이 긍정 적으로 변화하였다(Park et al., 2006). 초등학생을 대상으로 한 다양한 연구에 비해 중고등학생을 대상으로 장애이해교육의 효 과를 확인한 연구는 비교적 제한적이다(Lee, 2006; Na \& Kim, 2004). 중고등학생에 해당하는 청소년 시기에 차별적 장애인관 이나 편견이 형성되면 추후 긍정적으로 변화시키기 어려워 매 우 중요한 시기임에도 불구하고, 과중한 입시 교육 때문에 적극 적으로 장애이해교육을 시행하는 데 한계가 있다(Ha \& Yoo, 2012; Heo, 2012).

청각장애의 경우 보청기, 인공와우 등의 청각보조기기 기술 의 발달, 청각장애 조기 발견 및 중재 등의 결과로 인해 청각장 애학생의 통합교육 배치 수가 급증하였다. 연차 보고에 따르면 2002년도에 일반학교에 배치된 청각장애학생 수가 845명에 불 과하였으나, 2008년에는 1,844명, 2017년도에는 2,519명의 청각 장애학생이 일반학교에 재학하였다. 2017년도 기준 특수학교에 재학 중인 학생 수가 819명, 특수교육지원센터에 소속된 학생이 20 명인 것을 기준하였을 때 약 3 배가 넘는 청각장애학생 $(2,519$
명)이 일반학교에서 통합교육을 받고 있다(Career and Lifelong Education for Students with Disabilities Team, 2017). 이와 같 이 청각장애학생의 통합교육 비율이 꾸준히 증가하고 있음에도 불구하고 통합교육을 위한 지원이 청각장애가 아닌 타 장애 유 형에 집중되어 있어 만족스러운 서비스를 지원하지 못하고 있 고(Lee \& Park, 2018; Seo \& Yoo, 2014), 또래 일반학생들이 청각장애 혹은 청각장애학생과의 통합교육에 대해 긍정적인 태도를 가질 수 있도록 교육을 제공한 경우도 드물다(Lee \& Lee, 2012).

일반계 중고등학생이 장애에 대한 이해가 부족할 경우 부정 적으로 장애를 인식하고 장애학생을 괴롭히거나 놀리는 등의 행동을 보일 수 있어 장애이해 및 태도 개선을 위한 프로그램 을 제공하는 것이 매우 중요하다(Lee \& Ahn, 2011). 일반학생 들이 청각장애와 청각장애학생과의 통합교육에 대해 긍정적으 로 인식하기 위해서는 청각장애이해를 위한 교육이 선행되어야 한다. 따라서 본 연구에서는 일반계 중고등학생을 대상으로 이 해중심과 활동중심 프로그램을 포함하는 청각장애이해교육을 시행한 후 청각장애나 청각케어, 청각장애학생과의 통합교육에 대한 인식이 긍정적으로 변화하는지 확인하고자 하였다.

\section{MATERIALS AND METHODS}

\section{연구 대상}

본 연구는 울산광역시 남구, 중구, 북구에 위치한 5 개 학교 (중학교 4개교, 고등학교 1 개교)에 재학 중인 일반학생 150 명을 대상으로 하였다. 연구자가 직접 각 학교를 방문하여 청각장애 이해교육 프로그램을 시행하고, 프로그램 전후 설문조사를 하 였다. 연구를 위해 방문한 5개 학교에는 모두 특수학급이 존재 하였으나, 해당 학교에 재학 중인 청각장애학생은 없었다. 150 명의 설문 응답 중 대답한 내용의 완성도가 떨어지고 부적절하 게 응답한 8 명의 자료를 제외하여, 총 142 명의 결과를 최종 자 료로 처리하여 분석하였다. 설문 및 프로그램에 참여하기 전 연구 대상자에게 데이터의 익명성 등에 대한 설명을 하였고, 연 구 도중 자유롭게 연구 참여 철회가 가능함을 설명하였다. 대 상자 모두 연구 참여 전 연구의 목적 및 절차에 대한 설명을 듣 고 연구 참여에 동의하였다.

\section{연구 도구}

\section{청각장애이해 프로그램의 구성}

기존의 자료 배부 중심의 이론 수업보다는 이해중심과 활동 중심의 교육활동을 포함하는 것이 효과적이므로(Seo, 2017) 본 연구의 청각장애이해 프로그램에는 청각장애에 대한 정보 및 
지식을 전달하는 이해중심 교육과 청각장애를 직간접적으로 체험하는 활동을 포함하였다. 중고등학생을 대상으로 장애이해 교육을 시행한 선행연구에서는 대부분 8회 이상의 장기 프로그 램을 통하여 긍정적인 효과를 확인하였으나(Moon \& Park, 2006; Seo, 2017) 이와 같은 장기 교육 프로그램을 입시 위주의 중고등학교 교육 현실에 반영하기는 쉽지 않다. 본 연구에서는 2 교시에 걸쳐 총 90 분간 프로그램을 진행하였고 구체적인 교육 내용은 Appendix 1에 기입하였다.

1 교시 교육에는 다양한 정보와 지식을 전달하고 직간접적으 로 청각장애를 체험하는 데 목적을 두고 이해중심과 활동중심 교육을 포함하였다. 1교시의 이해중심 교육으로 귀의 해부생리 적 구조, 소리 전달 과정, 청각장애 종류 등에 대해 설명하였고, 난청의 발병률 및 난청이 삶에 미치는 영향, 소음성 난청의 위 험성 및 예방의 중요성에 대한 정보를 제공하였고, 청각장애를 극복하고 사회에서 인정받은 대표적 인물들을 소개하였다. 1교 시의 활동중심 프로그램에서는 청각장애에 대한 직간접적 체 험을 할 수 있게 하였다. 예를 들면 $60 \mathrm{~dB}$ 청각장애 시뮬레이션 을 통해(https://www.youtube.com/watch?v=K2nPeH_VwLc) $60 \mathrm{~dB}$ 의 청각장애를 가진 학생이 듣게 되는 소리를 간접 체험 하였고, receiver-in-canal (RIC) 형태의 보청기를 직접 착용 해 봄으로써 보청기를 통해 어떻게 소리가 들리는지, 보청기를 실제로 착용하였을 때 가지는 불편함 등을 체험하였다.

2교시의 경우 그룹 토의와 그룹 발표를 통한 이해중심 활동 을 진행하였다. 약 5 6명으로 그룹을 구성하여 또래의 청각장 애학생이 일상생활뿐 아니라 통합교육 수업 참여 시, 사회적 활 동 시 가질 수 있는 어려움에 대해 토의하게 하였다. 그룹별로 청각장애학생의 어려움을 해결해줄 수 있는 제품 혹은 서비스 등에 대해 발표하고 토론하는 시간을 가졌다.

\section{청각장애 및 청각장애학생과의 통합교육에 대한 인식 조사}

본 연구에서는 Kim \& Yang(2013)에서 청각장애 및 청각장 애 예방에 대한 의견을 설문조사하는 데 사용한 문항 20 개와 Lee(2008)가 통합교육에 대한 인식을 측정하는 데 사용한 문 항 31 개 중 본 연구의 목적에 부합하는 문항 21개를 선정한 후 필요에 따라 청각장애와 관련되도록 설문 문항을 수정하여 최 종 문항 15 개를 구성하였다.

총 15 개의 문항 중 문항 1 10번을 통하여 난청 예방 및 전반 적인 청각케어에 대한 이해 정도를 확인하였다(Appendix 2). 대 상자들은 각 문항을 읽고 Likert 5점 척도를 이용하여 답하였 으므로("매우 그렇다", “그렇다", "보통이다", "그렇지 않다", "전 혀 그렇지 않다") 점수가 높을수록 청각케어 및 난청 예방의 중 요성 등을 올바르게 이해하였음을 의미하였다. 문항 11 15번을 통하여 청각장애학생과의 통합교육에 대한 인식을 조사하였다.
각 문항에 대해 Likert 5점 척도를 이용하여 답하였고("매우 그 렇다", “그렇다", "보통이다", “그렇지 않다", “전혀 그렇지 않다"), 문항 15 번을 제외하고는 점수가 높을수록 청각장애학생과의 통합교육에 대해 긍정적으로 인식함을 의미하였다. 모든 문항 이 긍정적일 경우 전반적인 답에 영향을 줄 수 있어 문항 15 번 (“청각장애학생이 일반학생과 통합교육을 받을 경우 입시 경쟁 스트레스, 따돌림 등의 문제로 더 부정적인 영향을 받을 수 있 다.”)은 점수가 낮을수록 통합교육에 대해 긍정적으로 인식함 을 반영한다.

마지막으로 본 프로그램에서 시행한 4 개의 교육활동 $(60 \mathrm{~dB}$ 난청 시뮬레이션, 실제 보청기 착용, 난청 극복 인물 소개, 그룹 프로젝트 발표)에 대한 만족도를 설문하였다. 만족도 또한 Likert 5점 척도를 이용하여 답하게 하였으므로("매우 만족", “만족”, “보통”, “불만족”, “매우 불만족”) 점수가 높을수록 각 교 육활동에 만족하였음을 의미한다. 15 개 문항들에 대해 신뢰도 분석을 시행한 결과 크론바흐 알파 계수가 0.85 로 내적 일관성 이 비교적 높아 설문에 활용하기 적합함을 확인하였다.

그 외에 단답형 질문 13 개를 통하여 대상자의 일반적 특성 (대상자의 성별, 학년, 학급 환경 등에 대한 정보)과 개인 음향 기기 사용 습관 등에 대해 조사하였다(Appendix 3). 대상자의 개인 음향기기 사용 습관을 조사한 이유는 대상자 개인의 사 용 습관에 따라 청각장애의 위험성에 대한 인식 정도가 다른지 분석하기 위함이었다.

\section{통계 분석}

수집된 결과는 SPSS version 20.0 (IBM Corp., Armonk, $\mathrm{NY}, \mathrm{USA}$ ) 소프트웨어를 이용하여 분석하였고, 모든 통계 분 석은 유의수준 0.05 를 기준으로 하였다. 대상자의 일반적 특성 에 대한 응답은 빈도 분석으로 결과를 정리하였다. 청각장애이 해 프로그램 전후 설문조사를 시행하여 일반학생의 청각장애 및 청각케어에 대한 이해, 청각장애학생과의 통합교육에 대한 인식을 조사하였고, 본 연구에서 시행한 각 프로그램 활동에 대한 만족도를 조사하였다. 윌콕슨 부호순위 비모수 검정(Wilcoxon signed-rank test)을 실시하여 프로그램 전후 설문지 응 답을 비교하였다.

\section{RESULTS}

\section{대상자의 일반적 특성}

본 연구에 참여한 대상자 142 명의 인구학적 특성을 살펴보면 남학생이 45명(31.69\%), 여학생이 97명(68.31\%)이었고, 대상자 중 100명은 일반계 중학교 1학년(70.42\%), 26명이 중학교 2학년 (18.31\%), 16명이 고등학교 2학년(11.27\%)에 재학 중이었다. 대 
상자 모두 현재 재학 중인 학교에 특수학급이 있다고 대답하였 고, 이 중 110 명(77.46\%)이 통합교육을 경험한 적이 있었다. 전체 대상자 중 16명(11.27\%)만이 난청 혹은 난청 예방에 관련된 교 육을 받은 경험이 있다고 하였고, 대상자 중 27명(19.01\%)은 가 족, 친척, 혹은 지인 중 청각장애로 인해 보청기를 착용하는 사 람이 있다고 하였다. 대상자 중 101명(71.13\%)은 본인의 귀 건강 상태에 대해 건강하다고 느낀다고 하였고, 29명(20.42\%)은 보통, 12 명 $(8.45 \%)$ 은 예전보다 안 좋아진 것 같다고 응답하였다. 대상 자들의 음향기기 사용 습관에 대해 질문한 결과, 하루 음향기기 평균 사용 시간은 60 90분가량이었으며 음향기기를 주로 사용 하는 이유로는 동영상 시청(youtube, 드라마, 예능) 혹은 음악 청취의 목적이 주를 이루었다. 대상자 대부분(70\% 이상) 개인 음향기기 이용 후 귀가 윙 거리는 느낌이 들거나 소리가 잘 안 들 리는 느낌을 경험한 적 없다고 하였고, 개인 음향기기 사용 시 주변의 배경 소음이 있을 때 41명은 자주(28.87\%), 65명은 가끔 (45.77\%) 음향기기의 볼륨을 키운다고 답하였다.

\section{청각장애 및 청각장애학생과의 통합교육에 대한 인식 변화}

Table 1은 청각장애이해 프로그램 참여 전후 일반학생의 청 각장애 및 청각장애학생과의 통합교육에 대한 인식을 조사한 결과를 보여준다. 15 개의 문항 중 문항 1 10번의 경우 프로그 램 참여 전후 청각장애와 전반적인 청각케어 등에 대한 이해 정도를 조사하였고, 문항 11 15번을 통해서는 프로그램 참여 전후 일반학생의 청각장애학생과의 통합교육에 대한 인식이 긍 정적으로 변화하였는지 조사하였다(Appendix 1, 2).

문항별로 살펴보면 청각장애이해 프로그램 참여 전에 평균 점수가 4점 미만이었던 문항이 문항 $1,3,4,5,7,9,10,11,12$, 15 번이었다(Table 1). 문항 $1 \sim 10$ 번의 경우 점수가 높을수록 청 각케어 및 난청 예방의 중요성을 잘 이해하고 있음을 의미하며, 모든 문항에서 청각장애이해 프로그램 참여 전보다 참여 후에 점수가 유의미하게 증가하였다.

분석 결과 문항 1 번(“나는 난청 및 난청 예방에 대한 교육에 관심이 있다.”)의 경우 청각장애이해 프로그램 참여 전에는 평 균 3.53점, 참여 후 평균 4.32점으로 증가하여, 난청 및 난청 예 방에 대한 교육에 관심이 증가하였음을 알 수 있다. 문항 3 번 [“나는 이어폰을 장시간, 큰 소리로 사용하는 것으로 인하여 난 청이나 이명(윙 울리는 소리)이 생길 수 있다고 생각한다.”의 경우 프로그램 참여 전에는 평균 3.92점, 참여 후 평균 4.19점 으로 증가하여 큰 소리에 대한 노출이 난청 및 이명을 유발할 수 있음을 이해하게 되었다. 문항 4번(“시력이 나빠지면 안경을 쓰듯이 나에게 난청이 생길 경우 보청기를 적극적으로 사용할 것이다.”)의 경우 프로그램 참여 전에는 평균 3.58점, 참여 후 평균 4.07점으로 증가하여 보청기 사용에 긍정적인 태도를 보
Table 1. Mean score of each question (Q1-15) before and after participating in program

\begin{tabular}{cccccc}
\hline \multirow{2}{*}{ Question \# } & $\begin{array}{c}\text { Before } \\
\text { program }\end{array}$ & & $\begin{array}{c}\text { After } \\
\text { program }\end{array}$ & Z score & p value \\
\cline { 2 - 3 } \cline { 6 - 6 } & Mean (SD) & & Mean (SD) & & \\
\hline Q1 & $3.53(0.96)$ & & $4.32(0.72)$ & -6.56 & 0.000 \\
Q2 & $4.09(0.79)$ & & $4.37(0.68)$ & -2.85 & 0.000 \\
Q3 & $3.92(0.95)$ & & $4.19(0.82)$ & -2.41 & 0.016 \\
Q4 & $3.58(1.00)$ & & $4.07(0.69)$ & -4.55 & 0.000 \\
Q5 & $3.64(0.96)$ & & $4.35(0.64)$ & -6.60 & 0.000 \\
Q6 & $4.04(0.92)$ & & $4.45(0.67)$ & -3.90 & 0.000 \\
Q7 & $3.48(1.00)$ & & $4.33(0.66)$ & -7.05 & 0.000 \\
Q8 & $4.13(1.02)$ & & $4.39(0.74)$ & -2.29 & 0.022 \\
Q9 & $3.71(1.13)$ & & $3.99(0.75)$ & -2.15 & 0.031 \\
Q10 & $3.85(1.08)$ & & $4.25(0.61)$ & -3.46 & 0.001 \\
Q11 & $3.75(1.02)$ & & $4.25(0.75)$ & -4.38 & 0.000 \\
Q12 & $3.41(1.03)$ & $3.94(0.86)$ & -4.29 & 0.000 \\
Q13 & $4.03(0.86)$ & $4.12(0.82)$ & -0.99 & 0.319 \\
Q14 & $4.02(0.87)$ & $4.00(0.79)$ & -0.03 & 0.980 \\
Q15 & $2.58(0.96)$ & $2.66(1.14)$ & -0.65 & 0.518 \\
\hline
\end{tabular}

SD: standard deviation

였다. 문항 5 번(“나는 난청에 관한 교육이 소음성 난청을 예방 하는 데 도움이 된다고 생각한다.”)의 경우 프로그램 참여 전에 는 평균 3.64점, 참여 후 평균 4.35점으로 증가하였다. 문항 7번 (“난청이 무엇이고 난청을 예방하는 것이 왜 중요한지 잘 알고 있다.”)의 경우 청각장애이해 프로그램 참여 전 평균 점수가 3.48점으로 문항 1 10번 중 평균 점수가 가장 낮았으나, 프로그 램 참여 후 평균 점수가 4.33점으로 0.85 점 증가하였다. 즉, 프 로그램 참여 전에는 일반계 중고등학생들이 난청이나 난청 예 방에 대한 관심이 보통이었으나, 프로그램 참여 후 난청 예방 이 왜 중요한지 알게 되었고 이에 대한 관심이 생겼다고 답하였 다. 문항 9번(“내 귀의 건강을 위해 청력손실 방지를 위해 고안 된 이어폰을 구입할 의향이 있다.”)의 경우 프로그램 참여 전 평균 점수가 3.71점, 프로그램 참여 후 평균 점수가 3.99점으로 증가하였는데, 문항 9번은 문항 1 10번 중 프로그램 참여 후에 도 평균 4점(“그렇다”) 미만의 점수를 보인 유일한 문항이었다. 문항 10 번(“나는 청력을 보호하기 위해 개인 음향기기 사용 시 간을 줄이고 사용 패턴을 바꿀 의향이 있다.”)의 경우 프로그 램 참여 전 평균 점수가 3.85점, 프로그램 참여 후 평균 점수가 4.25점으로 증가하였다.

문항 1 10번 중 문항 2번, 문항 6 번, 문항 8 번은 프로그램 참 여 전에도 평균 점수가 4점 이상이었다. 문항 2번(“난청은 노인 뿐 아니라 청소년, 아동에게도 발생할 수 있으므로 정기적인 청 력검사가 필요하다.”)의 경우 프로그램 참여 전 평균 점수가 4.09점, 참여 후 평균 점수가 4.37점으로 증가하여 프로그램 참 여 후 정기적인 청력검사의 필요성에 대해 보다 올바르게 인식 
하게 되었음을 확인하였다. 문항 6번(“청소년기에 난청 예방 수 칙을 잘 지키면 나이가 들더라도 난청 시작 시기를 늦출 수 있다 고 생각한다.”)의 경우 프로그램 참여 전 평균 점수가 4.04점이었 고, 프로그램 참여 후 평균 점수가 4.45점으로 증가하였다. 문항 8번(“나는 청력을 보호하기 위해 개인 음향기기 사용 시 볼륨을 줄일 의향이 있다.”)의 경우 프로그램 참여 전 평균 점수가 4.13 점, 프로그램 참여 후 평균 점수가 4.39점으로 증가하였다. 문항 6번과 문항 8번 모두 프로그램 참여 후 점수가 유의하게 증가하 였으므로 본 프로그램 참여 후 청소년기부터 난청 예방의 수칙 을 잘 지키는 것이 중요하고 난청 예방을 위해 개인 음향기기 사 용 습관을 변경하려는 의지를 가지게 되었음을 알 수 있다.

문항 11 15번을 통해서는 청각장애학생과의 통합교육에 대 한 인식을 조사하였다. 앞서 설명하였듯이 문항 15 번(“청각장애 학생이 일반학생과 통합교육을 받을 경우 입시 경쟁 스트레스, 따돌림 등의 문제로 더 부정적인 영향을 받을 수 있다.”)을 제 외하고는 점수가 높을수록 청각장애학생과의 통합교육에 대해 긍정적으로 인식함을 의미하였다. 분석 결과 문항 11 번(“청각장 애 학생과의 통합교육을 긍정적으로 생각한다.”)의 경우 청각 장애이해 프로그램 참여 전 평균 점수가 3.75점, 프로그램 참여 후 평균 점수가 4.25점으로 점수가 증가하였다. 문항 12번(“청 각장애학생은 일반학생에 의해 언어 발달 및 듣기 능력이 촉진 될 것이다.”)의 경우에도 청각장애이해 프로그램 참여 전 평균 점수가 3.41점이었으나 프로그램 참여 후 평균 점수가 3.94점으 로 증가하였다. 그러나 문항 13 번, 14 번, 15 번의 경우 프로그램 참여 전보다 참여 후 점수가 유의하게 변화하지 않았다. 문항 13 번의 경우(“일반학생들은 청각장애학생과의 통합교육을 통 해서 다른 사람을 이해하고 배려하는 마음과 태도를 배울 수 있다.”) 프로그램 참여 전 평균 점수가 4.03점, 참여 후 평균 점 수가 4.12점이었다. 문항 14번의 경우(“통합교육은 청각장애학 생과 일반학생이 서로 이해하고 수용할 수 있는 상호작용의 기 회를 제공한다.”) 프로그램 참여 전 평균 점수가 4.02점, 참여 후 평균 점수가 4 점이었다. 문항 13 번과 14 번의 경우 프로그램 참여 전에 평균 점수가 이미 4점 이상으로 긍정적으로 인식하 고 있어서 프로그램 참여 후에 점수가 크게 증가하지도 저하되 지도 않아 통계적으로 유의한 차이를 보이지 않았다. 문항 15 번의 경우(“청각장애학생이 일반학생과 통합교육을 받을 경우 입시 경쟁 스트레스, 따돌림 등의 문제로 더 부정적인 영향을 받을 수 있다.") 청각장애이해 프로그램 참여 전 문항 15 번에 대한 평균 점수가 2.58점이었고 참여 후 평균 점수가 2.66점이 었다. 문항 15 번의 경우 점수가 낮을수록(“2점”: 그렇지 않다, "3점": 보통이다) 청각장애학생과의 통합교육을 긍정적으로 인 식하고 있음을 의미한다. 다른 문항(문항 1 14)에 비해 문항 15 번의 평균 점수가 비교적 낮으므로(약 2.6점) 본 연구에 참여한
일반학생들이 전반적으로 청각장애학생과의 통합교육에 긍정 적으로 생각하고 있음을 확인하였으나, 청각장애이해 프로그 램 참여 전보다 참여 후 통계적으로 유의한 차이를 보이지는 않았다.

\section{청각장애이해 프로그램 활동에 대한 만족도}

Appendix 1에 제시하였듯이 본 연구에서는 이해중심과 활 동중심의 교육을 위해 다양한 청각장애이해 활동을 포함하였 다. 프로그램이 끝난 후 본 연구에서 진행한 4 개의 대표적인 교 육활동에 대한 주관적 만족도를 조사하였다: 1) 청각장애를 극 복하고 사회에서 인정받은 대표적 인물 소개, 2) $60 \mathrm{~dB}$ 청각장 애 시뮬레이션, 3) RIC 보청기 시범 착용, 4) 그룹 토의 및 발표. 각 활동에 대한 주관적 만족도 응답 시 Likert 5점 척도를 이용 하였으므로(5: “매우 만족” 1: “매우 불만족”) 점수가 높을수록 만족도가 컸음을 의미한다(Table 2).

분석 결과 위의 활동 중 그룹 토의 및 발표(청각장애인의 어 려움에 대해 그룹 토의하고 어려움 해결을 위한 서비스 및 제 품에 대해서 그룹 발표)한 활동에 대한 평균 점수가 4.58점으 로 가장 만족도가 높았다. 두 번째로 만족도가 좋았던 활동은 청각장애를 극복하고 사회에서 인정받은 인물 소개로 평균 점 수가 4.46점이었다. 세 번째로 만족도가 좋았던 활동은 $60 \mathrm{~dB}$ 청각장애 시뮬레이션 체험으로 평균 만족도가 4.35점이었다. RIC 보청기를 착용해보는 활동의 경우 평균 만족도가 4.21점 으로 네 가지 활동 중 가장 낮은 점수를 보였다. 네 가지 활동 모두 평균 점수가 4점(“만족”) 이상이었음을 감안하면, 본 연구 에서 진행한 활동 대부분에 대해서 일반학생들이 비교적 만족 하고 흥미를 보였음을 알 수 있다.

\section{DISCUSSIONS}

장애이해교육이란 장애에 대한 지식 및 정보를 전달하고 장 애인의 어려움을 직간접적으로 체험하며 장애인을 생활 속에 서 돕는 방법 등에 대해 토의하는 기회를 제공하는 데 목적을 둔다. 일반학생에게 장애이해교육 프로그램을 시행할 경우 장 애학생이 지니고 있는 능력과 문제에 대해 보다 더 잘 이해하게

Table 2. Mean score of subjective satisfaction on each activity

\begin{tabular}{lcc}
\hline \multicolumn{1}{c}{ Activities } & Mean & SD \\
\hline $\begin{array}{l}\text { 1) Introduction of outstanding people who } \\
\text { have overcome hearing loss }\end{array}$ & 4.46 & 0.72 \\
2) Simulation of 60 dB hearing loss & 4.35 & 0.67 \\
3) Trial of receiver-in-canal hearing aids & 4.21 & 0.79 \\
4) Group discussion and presentation & 4.58 & 0.57 \\
\hline
\end{tabular}

SD: standard deviation 
되고 장애학생들에 대한 수용 태도가 긍정적으로 변화할 수 있다. 선행연구 결과 보다 어린 나이에 장애아동과 직접적인 상 호작용을 경험할수록 장애아동에 대한 태도 변화가 긍정적이 었다(Kim, 2007). 일반아동의 나이가 어릴수록 그리고 장애아 동과의 접촉경험이 적을수록 장애아동에 대한 태도가 보다 긍 정적이었으므로(Kwak et al., 1996) 장애에 대한 올바른 이해 없이 같은 교실에 배치하는 물리적 통합만 시행할 경우 오히려 부작용을 초래할 수 있어 장애에 대한 올바른 정보와 지식을 제공하고 장애에 대한 긍정적인 직간접적 경험의 기회를 제공 하는 장애이해교육의 시행이 중요하다.

다양한 선행연구에서 유아 및 초등학생을 대상으로 장애이 해 프로그램 활동을 시행하였고 대부분 긍정적인 효과를 보고 하였다. 예를 들어 Lee \& Kim(2004)은 128명의 유아를 대상 으로 동화 듣기, 이야기 나누기, 장애체험 활동 등을 시행한 결 과 다양한 장애이해 교육활동이 일반유아의 장애인식 및 태도 에 긍정적인 영향을 주었다고 하였다. $\operatorname{Han} \& \operatorname{Kim}(2004)$ 은 전 래놀이를 활용한 통합 프로그램을 경험한 유아 그룹이 경험하 지 않은 유아 그룹에 비해 장애유아를 더 긍정적으로 인식하였 음을 밝혔다. Cho \& Lee(2008)는 초등학교 아침활동 시간을 이용하여 장애이해교육을 시행한 결과 장애학생에 대한 태도 에 긍정적으로 영향을 미쳤다고 하였다. Seo et al.(2011)은 8회 에 걸쳐 장애이해 프로그램을 적용한 결과 프로그램에 참여했 던 초등학생일수록 장애학생에 대한 인식 및 태도가 긍정적으 로 변화하였고, Kang \& Chu(2009) 역시 총 22회기에 걸쳐 장 애이해 프로그램을 실시한 결과 장애학생에 대한 일반 초등학 생의 태도가 긍정적으로 변화하였다고 보고하였다.

다양한 연구에서 전반적인 장애이해교육 프로그램의 긍정적 인 효과를 보고하였으나 다른 장애 영역에 비해서 청각장애의 이해를 중점적으로 다루는 교육 프로그램에 대한 연구는 비교 적 부족한 편이다(Kang \& Chu, 2009). 청각장애학생과의 통합 교육에 대한 관심은 지속적으로 이루어져왔지만 대부분 청각장 애학생과의 통합교육에 대한 일반교사 및 학부모의 인식, 지원 에 대한 실태 조사가 주를 이루었다(Kwon \& Rhee, 2000; Oh, 2012; Seo \& Yoo, 2014). 반면 일반학생들을 대상으로 청각장애 혹은 청각장애학생과의 통합교육에 대해 어떻게 인식하고 있는 지에 대한 연구는 비교적 제한적이다.

청각장애 아동의 경우 나이가 어릴수록 일반학교에 통합되 어 교육을 받는 비중이 많으나 어린 나이에 통합교육 환경을 선택하였더라도 중고등학교 때 다시 청각장애 특수학교로 되돌 아가기도 한다. 학업 및 교우관계에서의 어려움으로 인한 학교 부적응, 의사소통의 어려움, 일반학생들의 따돌림 등으로 인한 정서적 위축, 청각장애에 대한 일반교사 및 일반학생들의 인식 부족 등이 그 이유인 것으로 보고되었다(Kim \& Choi, 2009;
Kwon, 2004). 청각장애학생과의 통합교육이 성공적으로 이루 어지려면 청각장애학생과 일반교사를 위한 지원 서비스도 중요 하지만 일반학생이 청각장애에 대해 올바르게 이해하고 청각장 애학생에 대한 부정적인 선입견을 가지지 않는 것이 중요하다.

본 연구에서는 일반계 중고등학생들에게 청각장애이해를 돕 는 프로그램을 통해 다양한 아이디어를 발표해 보는 시간을 가 졌다. 구체적으로는 1교시와 2교시 수업을 통해 청각장애에 대 한 정보를 제공하고 청각장애를 직간접적으로 체험하게 하였으 며, 그룹 토의 및 발표를 시행하였고, 1 교시와 2교시 수업을 통 해 청각장애에 대한 정보를 제공하고 청각장애를 직간접적으 로 체험하게 하였으며, 그룹 토의 및 발표를 통해 다양한 아이 디어를 발표해보는 시간을 가졌다. 본 연구에서 진행한 청각장 애이해 프로그램에 참여 후 설문에 사용한 문항 1 10번의 점수 가 모두 유의하게 증가하였다. 즉, 교육의 효과로 일반학생들이 청각장애에 대해 올바르게 이해하게 되었고 소음성 난청의 위 험성 및 예방에 대한 인식이 개선되었음을 확인하였다. 이러한 결과는 소음성 난청에 대한 캠페인을 진행한 후 대상자들의 신 념 및 지식이 유의하게 변화하였다고 보고한 선행연구와 유사 하다(Son, 2017). 중학생을 대상으로 45분씩 2회의 청소년 소 음성 난청 예방 교육을 실시한 결과에서도 소음성 난청 예방을 위한 의지가 개선되었음을 확인하였다(Kim \& Yang, 2013). 따 라서 청각장애에 대한 이해를 돕는 교육이 단기로 진행될지라 도 난청에 대한 이해 및 청각케어에 대한 의지, 난청의 위험성 에 대한 경각심을 일깨우는 데에 효과가 있다고 볼 수 있겠다.

본 연구에서 진행한 여러 활동 중 학생들의 주관적 만족도가 가장 높았던 활동은 그룹 토의와 그룹 발표 활동이었다. 그룹 토의 시 또래의 청각장애학생이 일상생활, 통합교육 수업 및 사 회적 활동에 참여할 때 가질 수 있는 어려움에 대해 토의하였 는데, 본 연구에 참여한 학생들이 가장 많이 논의했던 점이 청 각장애인의 교통안전에 대한 문제와 보청기 등의 청각보조기기 사용에 따른 미용에 관한 것이었다. 이를 극복할 수 있는 서비 스 및 제품에 대한 그룹 발표에서는 청각장애인이 자동차 소리 를 듣지 못해 발생할 수 있는 교통사고에 대비한 진동 손목시 계, 운전 시 발생할 수 있는 다양한 소리를 진동으로 알려주는 진동의자 및 경고등 설치 등에 대한 의견을 발표하였다. 또한, 보청기를 당당하고 멋스럽게 착용할 수 있게 도와줄 액세서리 형태의 보청기 개발 등 중고등학생답게 미용에 초점을 두어 다 양한 아이디어를 제시하였다.

본 연구에서 일반계 중고등학생을 대상으로 청각장애이해를 돕는 교육 프로그램을 시행한 결과 청각장애학생과의 통합교 육에 대해 갖는 태도가 다소 긍정적으로 변화하였으나 모든 문 항에서 결과가 유의하게 긍정적으로 변화하지는 않았다. $\operatorname{Kim}(2007)$ 은 학령 전기 비장애유아를 대상으로 청각장애에 대 
한 정보 전달, 모의 장애체험, 영상, 집단 토의 등 태도 개선 프 로그램을 시행하여 그 효과를 확인하였다. 실험 결과 프로그램 참여 후 13 개의 측정 항목 중 “도움, 관심, 호기심"의 3 개 항목 에서 긍정적인 효과가 있었으나 나머지 10 개의 항목에서는 유 의미한 차이가 없었다. 본 연구에서는 8회 이상의 장기적인 교 육 프로그램이 아닌 단 1 회의 교육을 진행하였기 때문에 한계 가 있었을 수 있다. 또한 본 연구에서는 다양한 영상자료를 활용 한 장애이해교육을 시행하지 못하였으므로 그 효과가 제한적이 었을 수도 있다. Ha \& Yoo(2012)는 통합경험이 없는 일반계 고 등학생을 대상으로 영상자료를 활용한 장애이해교육과 체험(봉 사) 활동 프로그램을 경험한 후 설문결과를 실시한 결과, 장애학 생에 대한 고등학생들의 태도가 긍정적으로 변화하였고 특히 영 상을 통한 장애이해 프로그램의 효과가 컸음을 밝혔다. 본 연구 에 참여한 연구 대상자 중 $77 \%$ 가량은 통합교육의 경험이 있었 으나 통합교육 경험 여부에 따라 청각장애학생과의 통합교육에 대한 인식이 유의하게 다르지 않았다. 일반학생이 장애학생과의 통합교육을 경험하였다 할지라도 긍정적이고 적극적인 상호작용 이 없었다면 장애학생을 공감하고 이해할 수 있는 경험을 가지 지 못했을 수 있다. 따라서 성공적인 통합교육을 위해서는 일반 학생과 장애학생이 서로 공감하고 이해할 수 있는 경험을 제공 하고 이에 대한 지속적이고 체계적인 교육이 필요하겠다.

본 연구의 제한점은 다음과 같다. 첫째, 본 연구는 울산 지역 의 일반계 중고등학교 학생들을 대상으로 하였기 때문에 후속 연구에서는 대상 학생을 전국 지역으로 확대하고 더 다양한 학 년의 학생들을 대상으로 연구를 해야 할 것이다. 둘째, 본 연구 에서는 장기적인 추적 관찰이 아닌 교육 전후 결과만을 비교 분석하였고, 교육의 효과가 수개월간 유지되는지 확인하지 못 하였다. Moon \& Park(2006)은 1회의 장애이해교육보다 지속적 으로 구조화된 장애이해교육 프로그램을 실시하면 장애학생에 대한 일반 고등학생의 수용태도가 보다 긍정적으로 변화할 수 있다고 하였다. 따라서 보다 체계적인 장기 연구를 통해 적절한 교육 횟수 및 기간을 알아보고, 교육 효과가 유지되는지 확인하 는 것이 필요하겠다.

중심 단어 : 장애이해 프로그램·청각장애·청각케어·통합교육.

\section{Ethical Statement}

This study has been approved by the Institutional Review Board of Hallym University of Graduate Studies (IRB: HUGSAUD497180).

\section{Acknowledgments}

The authors thank all the students who graciously gave their time and effort to participate in this study. We are grateful to schools and teachers for supporting this study.

\section{Declaration of Conflicting Interests \\ There are no conflict interests.}

\section{Funding}

N/A

\section{Author Contributions}

The authors contributed to all aspects of this work. C.K. and J.L. conceived research hypotheses and designed the experiments to reach the conclusion. J.L. provided critical feedback and overall direction and planning. C.K. collected and analyzed the data. C.K. and J.L. interpreted the results together and co-wrote the body of the manuscript. J.L. was responsible for handling revisions of the manuscript and proof reading up to the acceptance of the manuscripts.

\section{ORCID iDs}

Chan Mi Kim

Jae Hee Lee

https://orcid.org/0000-0002-5528-1933
https://orcid.org/0000-0002-4152-6434

\section{REFERENCES}

Career and Lifelong Education for Students with Disabilities Team. (2017, September). Special Education Annual Report. Regular National Assembly Report. Ministry of Education. Retrieved from https://www. moe.go.kr/boardCnts/view.do?boardID $=316 \& l e v=0 \&$ statusYN=C\&s $=$ moe\&m $=0302 \&$ opType $=$ N\&boardSeq $=72257$.

Cho, M. K. \& Lee, S. H. (2008). The effects of a disability-awareness program at early morning classes on elementary school students' attitudes toward students with disabilities. Special Education Research, 7(2), 5-26.

Cole, P. G. \& Chan, L. K. S. (1990). Method and Strategies for Special Education. New York, NY: Prentice Hall.

Ha, M. D. \& Yoo, E. J. (2012). The influences of a disability-awareness program on the attitudes of high school students without disabilities. The Journal of Special Children Education, 14(1), 203-220.

Han, J. O. \& Kim, H. J. (2004). A study on the effects of the traditional play programs on the attitudes of young children without disabilities towards their peers with disabilities in an inclusive classroom. Communication Sciences and Disorders, 9(1), 152-170.

Heo, H. (2012). The effect of a disability understanding educational program on general high school students' recognition toward integrated education (Unpublished master's thesis). Changwon National University, Changwon.

Kang, M. J. \& Choi, S. K. (2011). The study on correlation for inclusive teachers' perception toward inclusive education and satisfaction of support. Korean Journal of Physical and Multiple Disabilities, 54(4), 197217.

Kang, Y. \& Chu, Y. (2009). Effect of disability understanding program on non-disabled children's attitude toward disabled children. Journal of Developmental Disabilities, 13(1), 49-66.

Kim, H. J. \& Yang, S. J. (2013). The effects of education on the prevention of noise-induced hearing loss in adolescence. Journal of Korean Public Health Nursing, 27(2), 357-371.

Kim, M. K. (2007). The effect of young children's understanding and change in attitude toward the hard of hearing children program. Early Childhood Education Research and Review, 11(4), 175-197.

Kim, S. A. \& Choi, S. K. (2009). The qualitative research for reality, problems, and future direction on inclusion for students with hearing impairment. The Journal of Special Education: Theory and Practice, 10(4), 471-490.

Kwak, J. Y., Jin, K. N., \& Lee, I, S. (1996). A study on school children's attitudes toward friends with disabilities. Korean Journal of Social Welfare, 28(28), 39-55.

Kwon, S. H. \& Rhee, K. S. (2000). General education teacher's attitude towards behavior on inclusive education with hearing impairment. Communication Disorders, 23(3), 131-157.

Kwon, S. W. (2004). A case study on school adaptation of high school stu- 
dents with hearing impairment in inclusive settings. Speech and Hearing Disorders, 13(2), 27-48.

Lee, H. J. \& Park, E. (2018). Inclusive education for students with hearing impairment: A study of perceptions and experiences of general education teachers in elementary schools. Special Education Research, 17(3), 127-155.

Lee, H. S. (2008). A comparison of high school teacher's and student's consciousness on inclusive education (Unpublished master's thesis). Graduate School of Education Daegu University, Gyeongsan.

Lee, J. W. \& Lee, E. S. (2012). An effect of inclusive education fulfilled in deaf school on the perception of students with hearing impairment toward students with hearing. The Study of Education for Hearing-Language Impairments, 3(1), 127-141.

Lee, S. A. \& Kim, S. A. (2004). Changes in disability awareness and attitude of typically developing young children through disability-understanding activities. The Korean Journal of Early Childhood Special Education, 4(2), 113-136.

Lee, S. H. \& Ahn, H. S. (2011). A qualitative inquiry on realities and support needs regarding secondary inclusive education based on experiences and perceptions of students with disabilities and parents. Journal of Intellectual Disabilities, 13(1), 203-235.

Lee, W. R. (2006). A study of primary factors and attitude toward disability of middle \& high school students. The Journal of Special Education: Theory and Practice, 7(4), 385-403.

Moon, J. O. \& Park, J. Y. (2006). Effects of a disability-awareness program during homeroom classes on the attitudes of the highschool students toward individuals with disabilities. Special Education Research, 5(1), 51-72.

Na, S. H. \& Kim, J. K. (2004). A study on the changes in middle school students' attitudes toward students with disabilities through 'DisabilityAwareness Program' in optional activity classes. Korean Journal of
Special Education, 38(4), 209-229.

Oh, H. J. (2012). Review of transition education for inclusive education in elementary school for children with hearing impairment. The Study of Education for Hearing-Language Impairments, 3(1), 21-38.

Park, S. G., Lim, J. S., \& Seo, K. W. (2006). Attitudes of peers toward children with physical disability and mental retardation, learning disabilities, hearing impairment in an inclusive environment. The Educational Journal for Physical and Multiple Disabilities, 47, 221-244.

Peterson, N. L. (1982). Social integration of handicapped and nonhandicapped preschoolers: A study of playmate preferences. Topics in Early Child Special Education, 2(2), 56-69.

Seo, H. J., Kwon, M. O., \& Kim, S. Y. (2011). Effect of application of handicap understanding program on the awareness and attitude of the nonhandicapped toward children with handicap. Journal of Emotional and Behavioral Disorders, 27(2), 319-337.

Seo, J. H. \& Yoo, E. J. (2014). Survey on the understandings of general classroom teacher about educating students with hearing impairment and supporting the teacher of a inclusive school. The Journal of Special Education: Theory and Practice, 15(2), 203-230.

Seo, S. R. (2017). The effect of understanding-based and activity-based disability education on high school students' attitude toward disability and classroom atmosphere (Unpublished master's thesis). Korea National University of Education, Cheongju.

Son, H. K. (2017). The study on the effectiveness of the prevention campaign of noise-induced hearing loss focused on undergraduate students (Unpublished master's thesis). Woosong university, Daejeon.

Won, J. L. \& Um, S. J. (2007). Perspectives of principals and teachers regarding the essential support needed for successful inclusion: Preliminary study for the development of a consulting program. The Korean Journal of Early Childhood Special Education, 7(2), 47-81. 


\section{APPENDICES}

\section{Appendix 1. 청각장애이해 프로그램 내용}

\begin{tabular}{|c|c|c|}
\hline & 교육 종류 및 교육 목표 & 구체적인 교육 내용 \\
\hline \multirow{2}{*}{$\begin{array}{l}\text { 1교시 } \\
\text { (45분) }\end{array}$} & $\begin{array}{l}\text { 이해중심 교육: } \\
\text { 정보 및 지식 전달 }\end{array}$ & $\begin{array}{l}\text { 1) 귀의 해부생리적 구조와 소리의 전달 과정, 청각장애의 종류 } \\
\text { 2) 청각장애의 발병률 및 삶에 미치는 영향 } \\
\text { 3) 소음성 난청의 위험성 및 예방의 중요성 } \\
\text { 4) 청각장애를 극복하고 사회에서 인정받은 인물 소개 }\end{array}$ \\
\hline & $\begin{array}{l}\text { 활동중심 교육: } \\
\text { 청각장애에 대한 직간접적 경험 }\end{array}$ & $\begin{array}{l}\text { 5) 모의 청각장애 체험: } 60 \mathrm{~dB} \text { 의 청각장애 시뮬레이션 } \\
\text { 6) 보청기 착용 체험: 보청기를 통해 소리를 직접 들어보고 보청기 착용으로부터 } \\
\text { 발생되는 불편함 체험 }\end{array}$ \\
\hline $\begin{array}{l}\text { 2교시 } \\
\text { (45분) }\end{array}$ & $\begin{array}{l}\text { 이해중심 교육: } \\
\text { 그룹 토의 및 발표 }\end{array}$ & $\begin{array}{l}\text { 1) 그룹 토의: 또래의 청각장애학생이 일상생활, 통합교육 수업, 사회적 활동 } \\
\text { 참여 시 가질 수 있는 어려움에 대해 토의 } \\
\text { 2) 그룹 발표: 청각장애학생의 어려움을 해결해줄 수 있는 제품 혹은 서비스 } \\
\text { 등에 대해 그룹 프로젝트로 발표 }\end{array}$ \\
\hline
\end{tabular}




\section{Appendix 2. 청각장애 및 청각장애학생과의 통합교육에 대한 인식 조사를 위한 설문 문항}

\begin{tabular}{|c|c|c|c|c|c|c|}
\hline \multirow[t]{2}{*}{ 문항 } & \multirow[t]{2}{*}{ 질 문 } & $\begin{array}{l}\text { 매우 } \\
\text { 그렇다 }\end{array}$ & 그렇다 & 보통이다 & $\begin{array}{l}\text { 그렇지 } \\
\text { 않다 }\end{array}$ & $\begin{array}{c}\text { 전혀 } \\
\text { 그렇지 않다 }\end{array}$ \\
\hline & & 5 & 4 & 3 & 2 & 1 \\
\hline Q1 & 나는 난청 및 난청 예방에 대한 교육에 관심이 있다. & & & & & \\
\hline Q2 & $\begin{array}{l}\text { 난청은 노인뿐 아니라 청소년, 아동에게도 발생할 수 있으 } \\
\text { 므로 정기적인 청력검사가 필요하다. }\end{array}$ & & & & & \\
\hline Q3 & $\begin{array}{l}\text { 나는 이어폰을 장시간, 큰 소리로 사용하는 것으로 인하여 } \\
\text { 난청이나 이명(윙 울리는 소리)이 생길 수 있다고 생각한다. }\end{array}$ & & & & & \\
\hline Q4 & $\begin{array}{l}\text { 시력이 나빠지면 안경을 쓰듯이 나에게 난청이 생길 경우 } \\
\text { 보청기를 적극적으로 사용할 것이다. }\end{array}$ & & & & & \\
\hline Q5 & $\begin{array}{l}\text { 나는 난청에 관한 교육이 소음성 난청을 예방하는 데 도움이 } \\
\text { 된다고 생각한다. }\end{array}$ & & & & & \\
\hline Q6 & $\begin{array}{l}\text { 청소년기에 난청 예방 수칙을 잘 지키면 나이가 들더라도 } \\
\text { 난청 시작 시기를 늦출 수 있다고 생각한다. }\end{array}$ & & & & & \\
\hline Q7 & $\begin{array}{l}\text { 난청이 무엇이고 난청을 예방하는 것이 왜 중요한지 } \\
\text { 잘 알고 있다. }\end{array}$ & & & & & \\
\hline Q8 & $\begin{array}{l}\text { 나는 청력을 보호하기 위해 개인 음향기기 사용 시 볼륨을 } \\
\text { 줄일 의향이 있다. }\end{array}$ & & & & & \\
\hline Q9 & $\begin{array}{l}\text { 내 귀의 건강을 위해 청력손실 방지를 위해 고안된 } \\
\text { 이어폰을 구입할 의향이 있다. }\end{array}$ & & & & & \\
\hline Q10 & $\begin{array}{l}\text { 나는 청력을 보호하기 위해 개인 음향기기 사용 시간을 } \\
\text { 줄이고 사용 패턴을 바꿀 의향이 있다. }\end{array}$ & & & & & \\
\hline Q11 & 청각장애학생과의 통합교육을 긍정적으로 생각한다. & & & & & \\
\hline Q12 & $\begin{array}{l}\text { 청각장애학생은 일반학생에 의해 언어 발달 및 듣기 능력이 } \\
\text { 촉진될 것이다. }\end{array}$ & & & & & \\
\hline Q13 & $\begin{array}{l}\text { 일반학생들은 청각장애학생과의 통합교육을 통해서 다른 } \\
\text { 사람을 이해하고 배려하는 마음과 태도를 배울 수 있다. }\end{array}$ & & & & & \\
\hline Q14 & $\begin{array}{l}\text { 통합교육은 청각장애학생과 일반학생이 서로 이해하고 } \\
\text { 수용할 수 있는 상호작용의 기회를 제공한다. }\end{array}$ & & & & & \\
\hline Q15 & $\begin{array}{l}\text { 청각장애학생이 일반학생과 통합교육을 받을 경우 } \\
\text { 입시 경쟁 스트레스, 따돌림 등의 문제로 더 부정적인 } \\
\text { 영향을 받을 수 있다. }\end{array}$ & & & & & \\
\hline
\end{tabular}




\section{Appendix 3. 대상자의 일반 정보를 조사하기 위한 설문 문항}

*아래 중 해당하는 것에 동그라미 쳐주거나 숫자로 답을 기입하세요.

1) 나는 남 / 여

2) 나는 학년

3) 나는 장애학생과 같은 반에서 공부한 적이 있다 / 없다

4) 내가 다니는 학교에는 특수학급이 있다 / 없다

5) 이제까지 장애학생과 같은 반(통합교육)이었던 적이 있다 / 없다

6) 나는 난청 및 난청 예방에 관련된 교육을 받은 적이 있다 / 없다

7) 가족, 친척, 혹은 지인들 중 귀가 나빠 보청기를 착용하는 사람이 있다 / 없다

8) 나의 현재 청력 상태는 어떠하다고 생각하는가?

건강하다 / 보통이다 / 예전보다 안 좋아진 것 같다

9) 나는 이어폰을 착용하고 개인 음향기기(예시: 휴대폰, 태블릿 $\mathrm{PC}$, 아이패드/탭 등)를 일주일에 일 사용하며, 이용 시간은 하루에 총 분가량 사용한다.

10) 이어폰을 착용하고 개인 음향기기를 통해 많이 듣는 내용은? (중복 체크 가능) 동영상(유튜브, 드라마, 예능) / 음악 / 게임 / 인터넷 강의 / 운동 경기 / 라디오

11) 주변의 배경 소음이 있을 때 개인 음향기기의 볼륨을 크게 합니까?

자주 그렇다 / 가끔 그렇다 / 그렇지 않다

12) 개인 음향기기를 이용하고 난 후 이어폰을 뺐을 때 귀가 윙 거리는 듯한 느낌이 듭니까?

자주 그렇다 / 가끔 그렇다 / 그렇지 않다

13) 개인 음향기기를 이용하고 난 후 소리가 잘 들리지 않는 느낌이 듭니까?

자주 그렇다 / 가끔 그렇다 / 그렇지 않다 